\title{
Retraction Note to: Analysis of influential factors for predicting the shear strength of a V-shaped angle shear connector in composite beams using an adaptive neuro-fuzzy technique
}

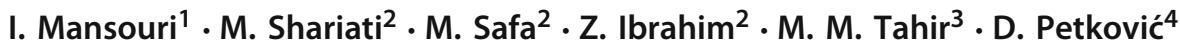

Published online: 12 November 2019

(c) Springer Science+Business Media, LLC, part of Springer Nature 2019

\section{Retraction Note to: J Intell Manuf (2019) 30:1247-1257 https://doi.org/10.1007/s10845-017-1306-6}

The Editor-in-Chief has retracted this article (Mansouri et al. 2019) because validity of the content of this article cannot be verified. This article showed evidence of authorship manipulation. None of the authors agree to this retraction.

\section{Reference}

Mansouri, I., Shariati, M., Safa, M., et al. (2019). Analysis of influential factors for predicting the shear strength of a V-shaped angle shear connector in composite beams using an adaptiveneuro-fuzzy technique. Journal of Intelligent Manufacturing, 30, 1247.

Publisher's Note Springer Nature remains neutral with regard to jurisdictional claims in published maps and institutional affiliations.
The original article can be found online at https://doi.org/10.1007/ s10845-017-1306-6.

M. Safa

maryamsafa1991@gmail.com

1 Department of Civil Engineering, Birjand University of Technology, Birjand, Iran

2 Department of Civil Engineering, University of Malaya, Kuala Lumpur, Malaysia

3 UTM CRC, Institute for Smart Infrastructure and Innovative Construction, UTM, Johor Bahru, Malaysia

4 University of Niš, Pedagogical Faculty in Vranje, Partizanska 14, Vranje 17500, Serbia 